\title{
Qu'est-ce qu'un texte technique ? Réflexions à propos de la Chine et des Andes
}

\section{Francesca Bray}

\section{(2) OpenEdition \\ Journals}

Édition électronique

URL : https://journals.openedition.org/tc/441

DOI : $10.4000 /$ tc. 441

ISSN : 1952-420X

Éditeur

Éditions de l'EHESS

\section{Édition imprimée}

Date de publication : 1 mai 1998

ISSN : 0248-6016

\section{Référence électronique}

Francesca Bray, "Qu'est-ce qu'un texte technique? Réflexions à propos de la Chine et des Andes », Techniques \& Culture [En ligne], 29 | 1998, mis en ligne le 28 octobre 2005, consulté le 29 septembre 2022. URL : http://journals.openedition.org/tc/441 ; DOI : https://doi.org/10.4000/tc.441

Ce document a été généré automatiquement le 29 septembre 2022.

Tous droits réservés 
Qu'est-ce qu'un texte technique? Réflexions à propos de la Chine et des Andes

Francesca Bray 